\title{
Quality of life, depressive and minor psychiatrics symptoms in nursing students
}

\author{
Qualidade de vida, sintomas depressivos e psiquiátricos menores em estudantes de enfermagem \\ Calidad de vida, síntomas depresivos y psiquiátricos menores en estudiantes de enfermería
}

\section{Jéssica Morgana Gediel Pinheiro' ORCID: 0000-0003-1530-7198}

Andreia Barcellos Teixeira Macedo' ORCID: 0000-0003-4219-4731

Liliana Antoniolli' ORCID: 0000-0003-0806-9910

Thayane Martins Dornelles' ORCID: 0000-0001-7377-7054

Juliana Petri Tavares' ORCID: 0000-0003-4121-645X

Sonia Beatriz Cocaro de Souza' ORCID: 0000-0001-9394-5465

'Universidade Federal do Rio Grande do Sul. Porto Alegre, Rio Grande do Sul, Brazil.

How to cite this article: Pinheiro JMG, Macedo ABT, Antoniolli L, Dornelles TM, Tavares JP, Souza SBC. Quality of life, depressive and minor psychiatrics symptoms in nursing students. Rev Bras Enferm. 2020;73(Suppl 1):e20190134. doi: http://dx.doi.org/10.1590/0034-7167-2019-0134

Corresponding author: Jéssica Morgana Gediel Pinheiro E-mail: jessica.mpinheiro@gmail.com

EDITOR IN CHIEF: Dulce Barbosa ASSOCIATE EDITOR: Mitzy Reichembach

Submission: 02-25-2019 Approval: 05-10-2020

\section{ABSTRACT}

Objective: To assess quality of life, prevalence of depressive and minor psychiatric symptoms in Nursing students. Methods: Cross-sectional study, conducted from March to April 2018, at a federal university. Sample composed of 242 Nursing students, from the $1^{\text {st }}$ to the $8^{\text {th }}$ semester. Data was collected using the quality of life instruments, Beck Depression Inventory and SelfReport Questionnaire. A significance level of 0.05 was considered. Results: The mean age was $22.9 \pm 5.1$ years. It was found that $25 \%$ of the students had severe depressive symptoms and $54 \%$ of the students had minor psychiatric disorders, with a higher prevalence in the first semesters. An inverse relationship was observed between the frequency of depressive symptoms and quality of life scores $(p=0.05)$. Conclusion: Nursing students showed a high prevalence of depressive symptoms, indicating the importance of implementing actions to promote and prevent mental health.

Descriptors: Health Student; Depression; Mental Disorder; Nursing Students; Life Quality.

\section{RESUMO}

Objetivo: Avaliar qualidade de vida, prevalência de sintomas depressivos e psiquiátricos menores em estudantes de Enfermagem. Métodos: Estudo transversal, realizado de março a abril de 2018, em uma universidade federal. Amostra composta por 242 acadêmicos de Enfermagem, do $1^{\circ}$ ao $8^{\circ}$ semestre. Os dados foram coletados por meio dos instrumentos de qualidade de vida, Inventário de Depressão de Beck e Self-Report Questionnaire. Considerou-se nível de significância de 0,05. Resultados: A média de idade foi de 22,9 $\pm 5,1$ anos. Verificou-se que $25 \%$ dos alunos apresentaram sintomas depressivos graves e $54 \%$ dos alunos apresentaram transtornos psiquiátricos menores, com maior prevalência nos primeiros semestres. Observouse relação inversa entre frequência de sintomas depressivos e escores da qualidade de vida $(p=0,05)$. Conclusão: Os acadêmicos de Enfermagem apresentaram elevada prevalência de sintomas depressivos, indicando a importância da implantação de ações para promoção e prevenção da saúde mental.

Descritores: Saúde do Estudante; Depressão; Transtornos Mentais; Estudantes de Enfermagem; Qualidade deVida.

\section{RESUMEN}

Objetivo: Evaluar calidad de vida, prevalencia de síntomas depresivos y psiquiátricos menores en estudiantes de Enfermería. Métodos: Estudio transversal, realizado de marzo a abril de 2018, en una universidad federal. Muestra compuesta por 242 académicos de Enfermería, del $1^{\circ}$ al $8^{\circ}$ semestre. Los datos han sido recogidos por medio de los instrumentos de calidad de vida, Inventario de Depresión de Beck y Self-Report Questionnaire. Se ha considerado nivel de acepción de 0,05. Resultados: La media de edad ha sido $22,9 \pm 5,1$ años. Se ha verificado que $25 \%$ de los alumnos presentaron síntomas depresivos graves y $54 \%$ de los alumnos presentaron trastornos psiquiátricos menores, con mayor prevalencia en los primeros semestres. Se ha observado relación inversa entre frecuencia de síntomas depresivos y escores de la calidad de vida $(p=0,05)$. Conclusión: Los académicos de Enfermería presentaron elevada prevalencia de síntomas depresivos, indicando la importancia de la implantación de acciones para promoción y prevención de la salud mental.

Descriptores: Salud del Estudiante; Depresión; Trastornos Mentales; Estudiantes de Enfermería; Calidad de Vida. 


\section{INTRODUCTION}

Entering graduation means a transition between stages of development, especially from adolescence to the stage of young adult, being a great challenge for most individuals, due to the need to seek their independence, make choices for adult life, define their career, be able to perform self-management, either for the study or for other individual issues. These behavioral change factors can generate anxiety, fear and stress. In such a context, these young people are faced with countless situations of social pressure, which influence the quality of life, generate fluctuations in mood and expressive changes in behavior, which can trigger psychic and mental illness ${ }^{(1)}$.

The arrival at the university does not mean a safe step, as it may be permeated by "fears and blocks" to be overcome, among other social and family factors related to the organization of each individual's personal life. First-year students often face, great difficulties. In France, the numerous failures and reorientations that occur in the first year testify to the difficulty of moving from high school to higher education ${ }^{(2-3)}$.

Thinking about entering university as a time of great demands and intellectual demand, it is understood that the university environment can harm or not promote the quality of life of university students. In addition, the student may face personal, social and/or economic vulnerability. The low quality of life is usually demonstrated by the presence of low self-esteem and low levels of satisfaction with life, which can generate depressive and anxiety symptoms, culminating in possible physical and/or psychological diseases if this condition is persistent or worsens ${ }^{(4-5)}$.

Quality of life is understood as the individual's perception of his insertion in life, in the context of the culture and value systems in which one lives and in relation to one's goals, expectations, standards and concerns. Therefore, this concept shows that quality of life will be perceived differently according to the "experience" of each individual ${ }^{(6)}$.

Studies carried out with higher education students presented as factors that trigger depressive disorders the excessive workload dedicated to studies, little time for leisure and extensive curricular content to be overcome ${ }^{(7-8)}$. Depression is one of the most common mental disorders and a major cause of morbidity and mortality worldwide, second only to anxiety disorders. It is a multifactorial disorder, and its triggering factors are still unclear ${ }^{(9-10)}$. It is estimated that 350 million people worldwide suffer from this disease and that, in 2030, depression is considered the major cause of disability, characterizing a notorious public health problem ${ }^{(11-12)}$.

Criteria for diagnosing depression include symptoms such as depressed mood most of the time, anhedonia, feeling of uselessness or excessive guilt, difficulty concentrating, fatigue or loss of energy, sleep disorders, psychomotor agitation or delay, significant loss or gain of weight observed in the absence of diet and, still, recurring ideas of death or suicide ${ }^{(13)}$.

Depressive disorders generate affective symptoms and can modify the way the person understands the events around them. Thus, it affects the way of seeing and living the lives of these people, decreases their perception of quality of life and can lead to serious consequences, such as suicide, if there is no treatment ${ }^{(9)}$.
Minor psychiatric disorders, in turn, are characterized by a set of symptoms including anxiety, insomnia, fatigue, irritability, forgetfulness, difficulty concentrating and somatic complaints. Evaluation carried out on Medical students from Bahia showed that $37.8 \%$ had minor psychiatric disorders, with higher prevalence in the $4^{\text {th }}$ semester ${ }^{(14-15)}$.

The knowledge gap that justifies this work refers to the scarcity of publications on the topics "quality of life/minor depressive and psychiatric symptoms in undergraduate Nursing students".

Given the above, this study asked: Is there a relationship between quality of life and prevalence of minor depressive and psychiatric symptoms in Nursing students at a public university in southern Brazil?

\section{OBJECTIVE}

To assess quality of life, prevalence of depressive and minor psychiatric symptoms in Nursing students at a public university in southern Brazil.

\section{METHODS}

\section{Ethical aspects}

The project was approved by the Ethics Committee of the Universidade Federal do Rio Grande do Sul (UFRGS). Confidentiality regarding the personal identification of the participants was guaranteed, as well as potential information that could identify them. The subjects who agreed to participate in the research signed the Free and Informed Consent Form.

\section{Study design and location}

Cross-sectional and analytical study, carried out from March to April 2018, at the Nursing School of the UFRGS. The Escola de Enfermagem (The Nursing School) of the Universidade Federal do Rio Grande do Sul (EENF) was founded on December 4, 1950. At the beginning of its activities, it was attached to the Faculty of Medicine of UFRGS.

The entrance exam is annual, always at the beginning of the year and aims to select students for admission in the $1^{\text {st }}$ and $2^{\text {nd }}$ semesters. Around 72 students enter the Nursing course annually, of which 36 are for universal admission and 36 for racial and social quotas for students who have completed high school in a public school.

\section{Population, sample, inclusion and exclusion criteria}

All students regularly enrolled in the undergraduate Nursing course at the UFRGS, over 18 and attending $1^{\text {st }}$ to $8^{\text {th }}$ semester. Students who returned the incomplete research protocol and were not present on the day of data collection were excluded.

The minimum sample was calculated using the WinPepi program, version 11.65 , considering a $95 \%$ confidence index, $10 \%$ margin of error, $50 \%$ proportion and $20 \%$ increase for possible losses and refusals. There were 93 participants, distributed among the first eight semesters. After approaching and guiding the objective of the study, 242 students agreed to participate. 


\section{Study protocol}

The research protocol consisted of a socio-demographic characterization questionnaire and the following instruments: The World Health Organization Quality of Life (WHOQOLBREF), the Self-Reporting Questionnaire (SRQ-20) and the Beck Depression Inventory (BDI).

The WHOQOL-BREF consists of 26 objective items, related to the analysis of the individual's quality of life ${ }^{(16)}$. It has four domains: Physical, Psychological, Social Relations and Environment ${ }^{(17)}$.

The calculations of the results of the WHOQOL-bref consist of verifying that all 26 questions were filled with values from 1 to 5 , in addition to the inversion of all questions whose scale of answers is contrary. The scores of the domains were calculated by adding the scores of the average of the " $n$ " questions that make up each domain (in the domains composed of up to 7 questions, the calculation was made only if the number of facets not calculated was not $\geq 2$; in the domains composed of more than 7 questions, it was performed only if the number of facets not calculated was not $\geq$ $3)$, the result being multiplied by 4 and represented on a scale of 4 to 20. The domain scores are converted to a scale from 0 to 100; individuals who did not complete (or incorrectly completed) more than 6 questions were excluded from the sample(18).

WHOQOL-BREF produces a quality of life profile. It is possible to assess the score of four domains (Physical, Psychological, Social Relations and Environment). There is the overall and two other items called Question 1 (Q1), which deals with the general perception of quality of life; and Question 2 (Q2), about the perception of your health in general ${ }^{(19)}$.

The Beck Depression Inventory (BDI) consists of 30 objective multiple choice questions. To perform the interpretation of scores, the following cut-off points are used: less than 10, without depression or minimal depression; between 10 to 18 , mild to moderate depression; between 19 to 29, moderate to severe depression; between 30 to 63, severe depression (20).

The SRQ-20 contains 20 objective questions, with only two answers (yes or no) - 4 questions are about physical symptoms; and 16, on psycho-emotional disorders. The cut-off score of the $\mathrm{SRQ}-20$ is $\geq 7$. These questions serve as a guide to have a minimum overview of the individual's non-psychotic psychic conditions, making it possible to perform a psychiatric symptom screening for referral to specialized care ${ }^{(21)}$.

\section{Analysis of results and statistics}

Quantitative variables were represented by the mean and standard deviation (SD) or mean and 95\% confidence interval [CI95\%], or by the median and interquartile range [percentil 25 and percentil 75] as a result of the Shapiro-Wilk normality test. Qualitative variables were represented by the absolute and relative frequency.

To compare qualitative variables, the chi-square test was performed; when significant, the standardized adjusted residue analysis was performed. For quantitative variables, the $t$ test for independent samples or the Mann-Whitney test was used; already, when comparing the semesters, ANOVA tests or the Kruskal-Wallis test were used.

Poisson Regression was performed for the Beck Score variable, with the objective of verifying whether the variable "semester" adjusted by other variables would change its effect. The analyses were performed using the Statistical Package for the Social Sciences (SPSS), version 25. The significance level adopted was 0.05 .

\section{RESULTS}

The sample consisted of 242 students, $88.8 \%(n=215)$ female and with an average age of $22.9 \pm 5.1$ years, within a range of 18 to 49 years. Among those surveyed, $30.2 \%(n=73)$ had a failure record in some discipline.

Regarding extra-class activities, 63.2\% (153) of the students answered that they perform some activity, of which, some perform more than one activity, corresponding to a total of 183 (67.3\%) answered extra-class activities.

Of the total, 124 (51.2\%) did not perform physical activity, and students in the $4^{\text {th }}$ semester had a higher percentage of non-practitioners $(71 \%, n=22)$. In contrast, the frequency of practitioners was higher among those in the $6^{\text {th }}(63.6 \%, n=21)$ and $7^{\text {th }}(64.3, n=$ 18) semesters $(p=0.05)$. With regard to leisure activities, $85.1 \%$ ( $=206$ ) of the students said they maintained some type of activity, with $65 \%(n=132)$ doing it up to twice a week.

Informed family history of mental illness, 120 students (49.8\%), with depression being the most prevalent among the illnesses $(44.1 \%, n=89)$ and that some had a history of more than one mental illness in the family. Of the 242 students, 33\% ( $n=80)$ reported having mental health monitoring, of which $45 \%$ ( $n=$ 36) with a psychiatrist and $55 \%(n=44)$ with a psychologist.

It was found that $77.2 \%(n=183)$ of the respondents did not report active disease. Among students who have any, chronic pain, attention deficit disorder and hyper/hypothyroidism stand out with a frequency of $2.9 \%(n=7)$ for each of the diseases. When evaluating the item "medication for continuous use", it was found that $44.9 \%$ (n $=106$ ) use some medication, especially the contraceptive, followed by psychotropic drugs, corresponding to $20.6 \%(n=28)$.

Table 1 shows the BDI distribution, in which $38.84 \%(n=94)$ of the students had no depression or minimal depression; $35.54 \%$ (n $=86$ ) of students, mild to moderate depression; $21.49 \%(n=52)$, moderate to severe depression; and 3.72\% $(n=9)$, severe depression.

The analysis of the association between Beck Depression Inventory scores and quality of life (Whoqol-Bref) was inversely proportional $(p=0.05)$. In the Inventory, the levels of moderate or severe depression increase while these individuals have lower averages in the Whoqol-Bref questionnaire, that is, the more severe the depressive symptoms, the lower the quality of life of the individuals, therefore inversely proportional, statistically significant.

Univariable Poisson regression was performed to verify the effect of each domain of the quality of life questionnaire in comparison with the findings of depressive symptoms in the SRQ20 ( $p=0.05)$. With regard to these comparisons, it was observed that, at each additional point in the Physical domain, there is a $5.6 \%$ reduction in the presence of depressive symptoms; at each point of increase in the Psychological domain, there is a $5.8 \%$ reduction in depressive symptoms; at each point of increase in the Social Relationship domain, there is a $3.4 \%$ reduction in depressive symptoms; at each point of increase in the Environment domain, there is a $3.8 \%$ reduction in depressive symptoms; at each point of increase in the overall result, there is a $25.7 \%$ reduction in depressive symptoms. 
Table 1 - Characterization of variables between depression scores (Beck Score) and univariate analysis of Poisson Regression, Porto Alegre, Rio Grande do Sul, Brazil, 2018

\begin{tabular}{|c|c|c|c|c|c|c|c|}
\hline & & BEC & & & UNIV & ABLE POISS & N REG \\
\hline & & $\begin{array}{l}\text { No depression or mild } \\
\quad(n=180[74,7 \%])\end{array}$ & $\begin{array}{l}\text { Moderate or severe } \\
(\mathrm{n}=61[25,3 \%])\end{array}$ & $\mathbf{P}$ & $\mathbf{R P}$ & [Cl95\%] & $\mathbf{p}$ \\
\hline $\mathrm{Age}^{1}$ & & $22.0[20.0 ; 25.0]$ & $21.0[19.0 ; 23.0]$ & 0.082 & 0.960 & {$[0.9 ; 1.0]$} & 0.233 \\
\hline $\operatorname{Sex}^{2}$ & $\begin{array}{l}\text { Male } \\
\text { Female }\end{array}$ & $\begin{array}{l}24(88.9) \\
156(72.9)\end{array}$ & $\begin{array}{c}3(11.1) \\
58(27.1)\end{array}$ & 0.098 & $\begin{array}{l}1.000 \\
2.439\end{array}$ & {$[0.8 ; 7.2]$} & 0.109 \\
\hline Disapproval & $\begin{array}{l}\text { No } \\
\text { yes }\end{array}$ & $\begin{array}{l}121(72) \\
59(80.8)\end{array}$ & $\begin{array}{c}47(28) \\
14(19.2)\end{array}$ & 0.200 & $\begin{array}{l}1.000 \\
0.686\end{array}$ & {$[0.4 ; 1.2]$} & 0.162 \\
\hline Family income & $\begin{array}{l}<1 \mathrm{MS} \\
1 \text { a } 2 \mathrm{MS} \\
3 \text { a } 4 \mathrm{MS} \\
>5 \mathrm{MS}\end{array}$ & $\begin{array}{l}13(54.2) \\
58(71.6) \\
66(76.7) \\
40(85.1)\end{array}$ & $\begin{array}{c}11(45.8) \\
23(28.4) \\
20(23.3) \\
7(14.9)\end{array}$ & 0.036 & $\begin{array}{l}3.077 \\
1.907 \\
1.561 \\
1.000\end{array}$ & $\begin{array}{l}{[1.4 ; 6.9]} \\
{[0.9 ; 4.1]} \\
{[0.7 ; 3.4]}\end{array}$ & $\begin{array}{l}0.007 \\
0.099 \\
0.265\end{array}$ \\
\hline Lives with the parents & $\begin{array}{l}\text { No } \\
\text { Yes }\end{array}$ & $\begin{array}{c}67(72.8) \\
113(75.9)\end{array}$ & $\begin{array}{l}25(27.2) \\
36(24.2)\end{array}$ & 0.711 & $\begin{array}{l}1.125 \\
1.000\end{array}$ & {$[0.7 ; 1.7]$} & 0.600 \\
\hline Semester ${ }^{2}$ & $\begin{array}{l}1^{\text {st }} \\
2^{\text {nd }} \\
3^{\text {rd }} \\
4^{\text {th }} \\
5^{\text {th }} \\
6^{\text {th }} \\
7^{\text {th }} \\
8^{\text {th }}\end{array}$ & $\begin{array}{c}23(62.2) \\
19(70.4) \\
24(75) \\
22(71) \\
16(80) \\
26(78.8) \\
23(82.1) \\
27(81.8)\end{array}$ & $\begin{array}{c}14(37.8) \\
8(29.6) \\
8(25) \\
9(29) \\
4(20) \\
7(21.2) \\
5(17.9) \\
6(18.2)\end{array}$ & 0.555 & $\begin{array}{l}2.081 \\
1.630 \\
1.375 \\
1.597 \\
1.100 \\
1.167 \\
0.982 \\
1.000\end{array}$ & $\begin{array}{l}{[0.9 ; 4.8]} \\
{[0.6 ; 4.1]} \\
{[0.5 ; 3.5]} \\
{[0.6 ; 4.0]} \\
{[0.4 ; 3.4]} \\
{[0.4 ; 3.1]} \\
{[0.3 ; 2.9]}\end{array}$ & $\begin{array}{l}0.085 \\
0.303 \\
0.507 \\
0.313 \\
0.869 \\
0.757 \\
0.974\end{array}$ \\
\hline SRQ20 ${ }^{2}$ (coded) & $\begin{array}{l}\leq 7 \\
>7\end{array}$ & $\begin{array}{l}109(100) \\
70(53.4)\end{array}$ & $\begin{array}{c}0(0) \\
61(46.6)\end{array}$ & $<0.001$ & & & \\
\hline SRQ20' (sum) & & $6.27(3.89)$ & $13.98(2.53)$ & $<0.001$ & 1.332 & {$[1.3 ; 1.4]$} & $<0.001$ \\
\hline $\begin{array}{l}\text { WQ - Physicist }{ }^{1}(0-100) \\
\text { WO - Psychological' (0- }\end{array}$ & & $\begin{array}{c}65.96(14.11) \\
60.66(9.95)\end{array}$ & $\begin{array}{l}48.09(12.43) \\
45.56(12.47)\end{array}$ & $\begin{array}{l}<0.001 \\
<0.001\end{array}$ & $\begin{array}{l}0.944 \\
0.942\end{array}$ & $\begin{array}{l}{[0.9 ; 1.0]} \\
{[0.9 ; 1.0]}\end{array}$ & $\begin{array}{l}<0.001 \\
<0.001\end{array}$ \\
\hline WQ - Social Relationsh & $(0-100)$ & $72.08(17.69)$ & $53.35(17.56)$ & $<0.001$ & 0.966 & {$[1.0 ; 1.0]$} & $<0.001$ \\
\hline WQ - Environment ${ }^{1}(0-$ & & $60.19(14.18)$ & $47.95(15.51)$ & $<0.001$ & 0.962 & {$[0.9 ; 1.0]$} & $<0.001$ \\
\hline WQ - Overall ${ }^{3}(0-20)$ & & $16.0[14.0 ; 16.0]$ & $12.0[10.0 ; 14.0]$ & $<0.001$ & 0.743 & {$[0.7 ; 0.8]$} & $<0.001$ \\
\hline WQ $-1^{\text {st }}$ Question (0-2 & & $18.8[18.8 ; 18.8]$ & $12.5[12.5 ; 18.8]$ & $<0.001$ & 0.858 & {$[0.8 ; 0.9]$} & $<0.001$ \\
\hline WQ $-2^{\text {nd }}$ Question $(0-2$ & & $18.8[12.5 ; 18.8]$ & $6.3[6.3 ; 12.5]$ & $<0.001$ & 0.881 & {$[0.9 ; 0.9]$} & $<0.001$ \\
\hline
\end{tabular}

Note:MS - Minimum salary per person. 1 - Representation by median [p25; 75 ]. Comparison by Mann-Whitney test; 2 - Representation by absolute and relative frequency. Chi-square comparison; 3 -Representation by mean (SD). Comparison by t test for independent samples.

\section{Scores of depressive symptoms per semester}

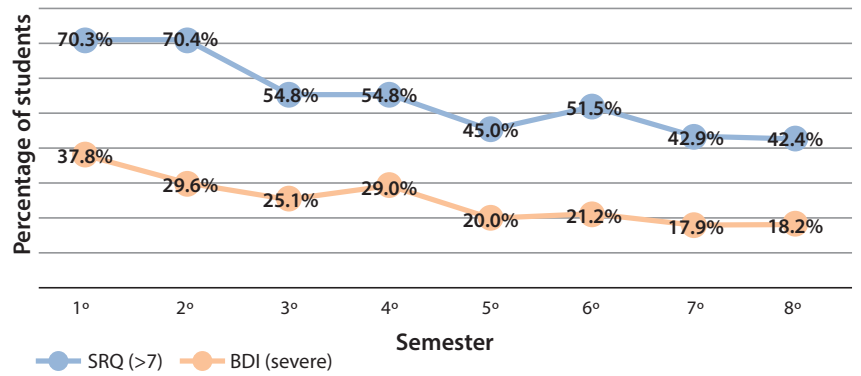

Note: BDI - Depression Beck Inventory, with only the most serious cases. SRQ - Self-Reporting Questionnaire, with scores greater than 7.

Figure 1 - Distribution of the mean percentage of depressive symptoms results - Porto Alegre, Rio Grande do Sul, Brazil, 2018

It was found that, at each point of increase in the Q1 domain, there is a $14.2 \%$ reduction in the presence of depressive symptoms; and at each point of increase in the Q2 domain, there is an $11.9 \%$ reduction in the presence of depressive symptoms.

There was no significant difference between the means (or distributions) of the quality of life domains between the semesters, and, regardless of the quality of life, the mean distribution of depressive symptoms remained the same between the groups separated by semester.

When comparing the BDI questionnaires and the SRQ20 questionnaire, they were directly proportional, that is, the higher the depression levels shown in the BDI, the higher the scores found in the SRQ20, as shown in Figure 1.

\section{DISCUSSION}

The prevalence of Nursing students with moderate or severe depressive symptoms was $25.3 \%$. This result is in line with a study carried out in Hong Kong with Nursing students, in which the prevalence of depressive symptoms was $24.3 \%{ }^{(22)}$. However, two other studies carried out in Bangladesh ${ }^{(23)}$ and Japan ${ }^{(24)}$ with Nursing students identified the prevalence of depression, with a rate of $46.8 \%$ and $43.1 \%$, respectively.

In 2018, an Irish study on the prevalence of depressive symptoms and suicidal ideation among first-year university students found that $59 \%$ of participants had depressive symptoms and $28.5 \%$ had suicidal ideation ${ }^{(25)}$. In a systematic review conducted in 2013 , it was observed that the prevalence rate of depressive symptoms in university students was $30.6 \%{ }^{(26)}$. Nursing students were above average (34\%), especially in Asia (43\%) ${ }^{(27)}$. Nursing students are more vulnerable to stress, anxiety and depression than non-nurses or non-doctors, due to the challenges of specialties, care skills and clinical practices ${ }^{(28)}$.

Among the findings, there was an association between depression, at moderate or severe level, and family income below 1 minimum salary per capita, corroborating the findings of the study of the prevalence of depressive symptoms among Nursing students, in which it is highlighted that income may be one of the factors significantly associated with depressive symptoms ${ }^{(22)}$. A study 
carried out at a higher education institution in Hong Kong found that students with financial difficulties are 2.3 times more likely to develop depressive symptoms ${ }^{(22)}$. It was also observed that age has been considered a determining factor in the emergence of stress, anxiety and depression in Nursing students, and the younger they are, the greater the chances of developing depression ${ }^{(29)}$.

The arrival at the university constitutes a remarkable phase for the students, since it requires adjustments and adaptations for a good academic performance. The changes demanded in this new phase, added to the stress and anxiety experienced by students during the entrance exam, can result in an increase in depressive symptoms ${ }^{(30)}$. These changes may be related to the transition between high school and graduation, suggesting that academic life can be a period of vulnerability, as it is associated, for many of the students, with "leaving home", consequently increasing independence, pressure and responsibility ${ }^{(31)}$.

It was observed that the higher the quality of life, the lower the scores of depressive symptoms. It is known that the concept of quality of life is subjective, multidimensional and includes positive and negative dimensions. It also covers the worldview and perceptions regarding the individual's physical, psychological and social aspects. Therefore, in this context, quality of life is related to the perception of expectations, goals and academic and personal achievements ${ }^{(32)}$.

The highest prevalence of depressive symptoms in this sample was concentrated in students of the first year of college, in which several coinciding factors are observed and which may contribute to the observed phenomenon. In a study carried out in India with Nursing students, it was identified that depressive symptoms had higher levels during the first year of graduation, reducing during the course $\mathrm{e}^{(33)}$. In contrast, a study with Nursing students in Sri Lanka identified an association between years of study with depressive symptoms ${ }^{(34)}$. The high number of hours, the multiple basic subjects with high demand due to tests, assignments and the amount of content allocated in these stages of the curriculum can generate sleep deprivation and stress ${ }^{(35)}$.

In a study with undergraduate students of Law, Psychology and Veterinary Medicine, the stress process was triggered by the adaptation to the university environment, as a result of the greater demand on the results, requiring the student to make an abrupt transition as to their adaptation to the new moment of life, which can trigger depressive symptoms ${ }^{(7)}$. Another research with medical students, in order to assess depression and anxiety, pointed out that one of the possible causes for depressive disorders was the excessive workload dedicated to studies, little time for leisure and an extensive curricular content to be overcome ${ }^{(8)}$.

Factors such as age, income, long hours and quality of life can contribute to academic performance, since, according to a study carried out in Portugal, $30.2 \%$ of students have already failed. Young people are just as susceptible to mental disorders, such as anxiety, stress and depression as adults, perhaps even worse, as all feelings and emotions take on great proportions at this stage ${ }^{(29)}$.

Depression is a disease considered to be multifactorial, characterized by a lasting change in mood, which may or may not be accompanied by some modification of the individual's personal perspectives and/or important biological functions. Predisponents refer to circumstances of a genetic or psychological nature that enable a person to develop depression ${ }^{(30)}$.
Knowing that it is a multifactorial disease and considering that one of the contributing components for its emergence is heredity, it was observed that, among the 242 students surveyed, at least $44 \%$ had a history of family depression, in addition to other psychiatric diseases, such as bipolarity and anxiety disorder ${ }^{(30)}$.

Even though there is no significant difference between the groups, it is important to consider that the quality of life remained at a similar average between the semesters, as observed in a study with 238 university students, from semesters and varied courses, in two Portuguese educational institutions ${ }^{(36)}$. However, when analysing the quality of life in conjunction with individuals who presented moderate or severe depressive symptoms, a reduction in quality of life was observed, which characterizes an expected outcome for such situation ${ }^{(37)}$.

Minor psychiatric disorders followed the same curve shown by the Beck Depression Inventory scores and are also inversely proportional to the quality of life curve. The same can be observed in a study with seminarians in São Paulo/Brazil: the higher the charges, the higher the scores for minor psychiatric symptoms, as well as the lower scores for quality of life $\mathrm{f}^{(38)}$.

The survey found that the majority of respondents were female, perhaps due to the fact that, for historical reasons, it is a mostly female course. In a study carried out with health students in Rio Grande do Sul/Brazil, it was observed that the highest occurrence of minor psychiatric disorders was in female students of the Nursing course ${ }^{(15)}$.

The findings of the present study indicate a prevalence of depression 2.4 times higher among female students. In a study carried out in the Nursing course at a public university in Northeastern Brazil, a prevalence of depressive symptoms was evidenced in $30.2 \%$ of students, being twice as high in women ${ }^{(39)}$.

\section{Study limitations}

It is understood as a limitation of the study the fact that it was an intentional and convenience sample, since only students present on the day the questionnaire was applied were included.

\section{Contributions to the area of Nursing, Health or Public Policy}

The study contributes to highlight the vulnerability of Nursing students in the face of adversities in the academic world. It was possible to verify that the greatest propensity to the development of depressive symptoms is present in the first semesters of college. This brings up a problem that still does not receive enough attention. Therefore, the results presented can contribute to projects of insertion and psychological assistance to university students, especially in the first years of graduation.

\section{CONCLUSION}

The study identified a high prevalence of minor psychiatric symptoms and depressive symptoms. It was found that $25 \%$ of students had severe depressive symptoms and $54 \%$ of students had minor psychiatric disorders, with higher prevalence in the first semesters. Also, the prevalence of minor depressive symptoms was inversely related to the quality of life scores.

In view of these results, it is suggested that higher education institutions expand spaces for reflection on mental health in the academic environment and value the implementation of 
programs for psychological support to students, so that they can discuss their personal problems with specialized professionals and improve their quality of life.

In this sense, the elaboration and reinforcement of strategies for coping with difficult situations in academic life could both contribute to reduce university dropout and prevent the development of limiting mental disorders

It is worth mentioning that the care with these young academics can help in the formation of healthy adults and better nursing professionals.

\section{REFERENCES}

1. Claudino J, Cordeiro R. Níveis de ansiedade e depressão nos alunos do curso de licenciatura em enfermagem: o caso particular dos alunos da Escola Superior de Saúde de Portalegre. Millenium [Internet]. 2006 [cited 2020 Apr 28];32:197-210. Available from: http://revistas.rcaap. $\mathrm{pt} / \mathrm{millenium/article/view/8403}$

2. Ferreira SAS. Estratégias de diálogo com o estranhamento no começo da vida universitária: políticas de acolhimento e permanência na Universidade Federal do Sul da Bahia. Rev Inter Educ Sup. 2017;3(2):291-307. doi: 10.22348/riesup.v3i2.7757

3. Coulon A. O ofício de estudante: a entrada na vida universitária. Educ Pesqui. 2017;43(4):1239-50. doi: 10.1590/S1517-9702201710167954

4. Pires R, Danilo R, Silva ASF, Fagulha T. Relações entre a qualidade de vida e os estilos de personalidade medidos com a adaptação Portuguesa do Índice de Estilos da Personalidade de Millon-MIPS-R (Edição Revista). Rev Iberoam Diagn Eval Psicol [Internet]. 2014 [cited 2020 Apr 28];1(37):53-72. Available from: https://www.aidep.org/sites/default/files/articles/R37/Art3.pdf

5. Garcia Jr CAS, Ferracioli JA, Zajankauskas AE, Dias NC. Depressão em médicos da Estratégia de Saúde da Família no município de Itajaí/SC. Rev Bras Med Fam Comunidade. 2018;13(40):1-12. doi: 10.5712/rbmfc13(40)1641

6. World Health Organization. The World Health Organization Quality of Life Assessment (WHOQOL): position paper from the World Health Organization. Soc Sci Med. 1995;41(10):1403-09. doi: 10.1016/0277-9536(95)00112-K

7. Teixeira MAP, Castro GD, Piccolo LdaR. Adaptação à universidade em estudantes universitários: um estudo correlacional. Interaçao Psicol. 2007;11(2):211-20. doi: 10.5380/psi.v11i2.7466

8. Vasconcelos TCD, Dias BRT, Andrade LR, Melo GF. Barbosa L, Souza E. Prevalência de sintomas de ansiedade e depressão em estudantes de medicina. Rev Bras Educ Méd. 2015;39(1):135-42. doi: 10.1590/1981-52712015v39n1e00042014

9. Cai X, Kallarackal AJ, Kvarta MD, Goluskin S, Gaylor K, Bailey AM, et al. Local potentiation of excitatory synapses by serotonin and its alteration in rodent models of depression. Nat Rev Neurosci. 2013;16(4):464-72. doi: 10.1038/nn.3355

10. Gordon JL, Girdler SS. Hormone replacement therapy in the treatment of perimenopausal depression. Curr Psychiatr Rep. 2014;16:517. doi: $10.1007 / \mathrm{s} 11920-014-0517-1$

11. Haase J, Brown E. Integrating the monoamine, neurotrophin and cytokine hypotheses of depression - A central role for the serotonin transporter?. Pharmacol Ther. 2015;147:1-11. doi: 10.1016/j.pharmthera.2014.10.002

12. Haberstick BC, Boardman JD, Wagner B, Smolen A, Hewitt JK, Killeya-Jones LA, et al. Depression, stressful life events, and the impact of variation in the serotonin transporter: Findings from the National Longitudinal Study of Adolescent to Adult Health (Add Health). PLos ONE. 2016;11(3):1-13. doi: 10.1371/journal.pone.0148373

13. Scott KM, Lim CC, Hwang I, Adamowski T, Al-Hamzawi A, Bromet E, et al. The cross-national epidemiology of DSM-IV intermittent explosive disorder. Psychol Med. 2016;46(15):3161-72. doi: 10.1017/S0033291716001859

14. Silva PAS, Rocha SV, Santos LB, Santos CA, Amorim CR, Vilela ABA. Prevalência de transtornos mentais comuns e fatores associados entre idosos de um município do Brasil. Ciênc Saúde Colet. 2018;23(2):639-46. doi: 10.1590/1413-81232018232.12852016

15. Silva RS, da Costa LA. Prevalência de transtornos mentais comuns entre estudantes universitários da área da saúde. Encontro[Internet]. 2012 [cited 2020 Apr 28];15(23):105-12. Available from: https://revista.pgsskroton.com/index.php/renc/article/view/2473

16. Fleck MPA, Louzada S, Xavier M, Chachamovich E, Vieira G, Santos L, et al. Aplicação da versão em português do instrumento abreviado de avaliação da qualidade de vida "WHOQOL-bref". Rev Saúde Pública. 2000;34(2):178-83. doi: 10.1590/S0034-89102000000200012

17. Pedroso B, Pilatti LA, Gutierrez GL, Picinin CT. Cálculo dos escores e estatística descritiva do WHOQOL-bref através do Microsoft Excel. Rev Bras Qual Vida. 2010;2(1):31-6. doi: 10.3895/S2175-08582010000100004

18. Pedroso B, Ferreira BMP. Cálculo dos escores e estatística descritiva do WHOQOL-8 por meio do Microsoft Excel. Rev Bras Qual Vida. 2015;7(2):113-5. doi: 10.3895/rbqv.v7n2.2995

19. World Health Organization. WHOQOL-BREF - Introduction, Administration, Scoring and Generic Version of the Assessment - Field Trial Version [Internet]. Dec 1996 [cited 2020 Apr 28]. Geneva, World Health Organization. Available from: https://www.who.int/mental_health/ media/en/76.pdf.

20. Gorenstein C, Andrade L. Inventário de depressão de Beck: propriedades psicométricas da versão em português. Rev Psiquiatr Clín[Internet]. 1998 [cited 2020 Apr 28];25(5):245-50 Available From: https://www.researchgate.net/ publication/284700806_Inventario_de_depressao_de_Beck_Propriedades_psicometricas_da_versao_em_portugues 
21. Gonçalves DM, Stein AT, Kapczinski F. Avaliação de desempenho do Self-Reporting Questinnaire como instrumento de rastreamento psiquiátrico: um estudo comparativo com o Structured Clinical Interview for DSM-IV-TR. Cad Saúde Pública. 2008;24(2):380-90. doi: 10.1590/ S0102-311X2008000200017

22. Cheung T, Wong S, Wong K, Law L, Ng K, Tong M, et al. Depression, anxiety and symptoms of stress among baccalaureate nursing students in Hong Kong: a cross-sectional study. Int J Environ Res Public Health. 2016;13(8):779-803. doi: 10.3390/ijerph13080779

23. Hossain S, Anjum A, Uddin ME, Rahman MA, Hossain MF. Impacts of socio-cultural environment and lifestyle factors on the psychological health of university students in Bangladesh: a longitudinal study. J Affect Disord. 2019;256:393-403. doi: 10.1016/j.jad.2019.06.001

24. Kono K, Eskandarieh S, Obayashi Y, Arai A, Tamashiro H. Mental health and its associated variables among international students at a Japanese university: with special reference to their financial status. J Immigr Minor Health. 2015;17(6):1654-59. doi: 10.1007/ s10903-015-0256-3

25. Horgan A, Kelly P, Goodwin J, Behan L. Depressive Symptoms and Suicidal Ideation among Irish Undergraduate College Students. Issues Mental Health Nurs. 2018;39:575-84. doi: 10.1080/01612840.2017.1422199

26. Ibrahim AK, Kelly SJ, Adams CE, Glazebrook C. A systematic review of studies of depression prevalence in university students. J Psychiatr Res. 2013;47(3):391-400. doi: 10.1016/j.jpsychires.2012.11.015

27. Tung YJ, Lo KKH, Ho RCM, Tam WSW. Prevalence of depression among nursing students: A systematic review and meta-analysis. Nurse Educ Today. 2018;63:119-29. doi: 10.1016/j.nedt.2018.01.009

28. Hsiung D, Tsai C, Chiang L, Ma W. Screening nursing students to identify those at high risk of poor mental health: a cross-sectional survey. BMJ Open. 2019;9:e025912. doi: 10.1136/bmjopen-2018-025912

29. Cruz CMVM, Pinto JR, Almeida M, Aleluia S. Ansiedade nos estudantes do ensino superior - Um Estudo com Estudantes do $4^{\circ}$ Ano do Curso de Licenciatura em Enfermagem da Escola Superior de Saúde de Viseu. Millenium [Internet]. 2010 [cited 2020 Apr 28$] ; 38(1): 223-42$. Available from: http://hdl.handle.net/10400.19/305

30. Ramos FP, Silva SC da, Freitas DF de, Gangussu LMB, Bicalho AH, Sousa BV de O, et al. Fatores associados à depressão em idoso. REAS. 2019;19:e239. doi: 10.25248/reas.e239.2019

31. Verger P, Combes JB, Kovess-Masfety V, Choquet M, Guagliardo V, Rouillon F, et al. Psychological distress in first year university students: socioeconomic and academic stressors, mastery and social support in young men and women. Soc Psychiatr Psychiatr Epidemiol. 2009;44(8):643-50. doi: 10.1007/s00127-008-0486-y

32. do Prado MCR, Calais SL, Cardoso HF. Stress, Depressão e Qualidade de Vida em Beneficiários de Programas de Transferência de Renda. Interação Psicol. 2016;20(3):330-40. doi: 10.5380/psi.v20i3.35133

33. Chatterjee S, Saha I, Mukhopadhyay S, Misra R, Chakraborty A, Bhattacharya A. Depression among nursing students in an Indian government college. Br J Nurs. 2014;23(6):316-20. doi: 10.12968/bjon.2014.23.6.316

34. Rathnayake S, Ekanayaka J. Depression, anxiety, and stress among undergraduate nursing students in a public university in Sri Lanka. Inter J Caring Sci[Internet]. 2016 [cited 2020 Apr 28];9(3):1020-32. Available from: https://pdfs.semanticscholar.org/1134/0b1668b1059b09c9b9bb 1 bec140758e0eada.pdf

35. Hirsch CD, Barlem ELD, Tomaschewski-Barlem JG, Lunardi VL, de Oliveira ACC. Preditores do estresse e estratégias de coping utilizadas por estudantes de Enfermagem. Acta Paul Enferm. 2015;28(3):224-9. doi: 10.1590/1982- 0194201500038

36. Vizzotto MM, Jesus SN, Martins AC. Saudades de casa: indicativos de depressão, ansiedade, qualidade de vida e adaptação de estudantes universitários. Rev Psicol Saúde. 2017;9(1):59-73. doi: 10.20435/pssa.v9i1.469

37. Baptista MN, Morais PR, Carmo NC, Souza GO, Cunha AF. Avaliação de depressão, síndrome de burnout e qualidade de vida em bombeiros. Psicol Argum [Internet]. 2005 [cited 2020 Apr 28];23(42):47-54. Available from: https://periodicos.pucpr.br/index.php/psicologiaargumento/ article/view/20009/19297

38. Andrade DP, Souza JC, Figueiró MT, Andrade KO, Andrade VO. Qualidade de vida e transtornos psíquicos menores em seminaristas católicos. Rev Psicol Saúde. 2017;9(1):93-110. doi: 10.20435/pssa.v9i1.562

39. Fernandes MA, Vieira FER, Silva JS, Avelino FVSD, Santos JDM. Prevalência de sintomas ansiosos e depressivos em universitários de uma instituição pública. Rev Bras Enferm. 2018;71(s5):2169-75. doi: 10.1590/0034-7167-2017-0752 